\title{
Economic Potential of Handicrafts of Jammu and Kashmir
}

\author{
Ishfaq Ahmad Bhat \\ Urichersoo Pulwama, Jammu and Kashmir \\ M.A, M.PHIL, JKSET ECONOMICS, PRESENTLY PURSUING B.ED
}

\begin{abstract}
Handicraft activities occupy an important position in the economic structure of J\&K State. Being environment friendly, these activities are best suited to the state as they are more labour intensive and less capital intensive in nature, therefore having scope for employment generation at a large scale. The Kashmir handicraft products have earned worldwide fame for their attractive designs, functional utility and high quality craftsmanship. In absence of other manufacturing industries in the state, handicrafts remained a key economic activity from time immemorial. The present study focuses on the potential of handicrafts of the state of Jammu and Kashmir and analyses its various aspects.
\end{abstract}

Keywords: Handicrafts, State Economy, GSDP, Growth rate

\section{Introduction}

Prior to 1947, agriculture was the mainstay of the people in the country. Soon after independence, the government felt the need for economic regeneration of the country. Thus, in 1948, the Industrial Policy Resolution 1948 was adopted in which industries were classified in four categories and the role of cottage and small scale industries was duly recognized. Later in 1951, Industrial Development and Regulation Act was passed to regulate the process of industrialization. With the achievement of independence, a new hope dawned on the Handicraft horizon and people began to display their interest in its development. The Central Government paid special attention for the development of this sector throughout the length and breadth of this country. Keeping in view the employment potential of small-scale and cottage industries, Industrial Policy statement of 1956 emphasized on the development of Handicraft sector.

\section{History of Handicrafts in Jammu and Kashmir}

Jammu and Kashmir which is recognized as heaven on earth has also enjoyed its world-wide fame in Handicraft industry. The history of the state Handicrafts has been long and interesting. One of the most glorious periods has been that of King Zain-ul-Abidin (A.D. 1420-70) popularly known as Badshah- the great king. It was he who invited talented craftsmen from Central Asia and got them settled here to disseminate their skills. Later during the period 1450-1850 A.D, Maharaja Gulab Singh encouraged the Handcrafts in the state. His successor, Maharaja Partap Singh also took interest in the development of arts and crafts in the state. But during the reign of Maharaja Hari Singh, the Handicraft sector received a major setback because of the policy of replacing hand-made goods by machine-made goods. However, in the beginning of 20th century the Handicraft industry of Jammu and Kashmir was revived. The handicraft products have won worldwide acclaim for their exquisite designs, craftsmanship and functional utility.

\section{Objectives}

The study has been undertaken with the following objectives in view:

1) To identify the contribution of Handicraft sector in the economy of the state.

2) To assess the growth and performance of Handicraft industry of state.

3) To examine the policies and schemes initiated by Government for the growth and development of handicraft industries.

\section{Hypothesis}

$\mathbf{H}_{\mathbf{0}}$ : Contribution of Handicraft industry to the state economy has increased over the period of time.

$\mathbf{H}_{1}$ : Contribution of handicrafts to the state economy has declined over period of time.

\section{Review of Literature}

In order to gain background knowledge of problem and to identify appropriate methodology, research design and techniques of analysis or to be able to formulate the problem precisely, a brief review of the literature relating to the field under study has been presented.

1) Ghulam Nabi (1975) in his study made an analysis into the growth of carpet industry in the state since its inception. In the pre-independence period, industry has not grown at a steady rate, however after independence, the industry made considerable progress. The author has thrown some light on the cost structure of carpet industry. He says the major constituents of costs are raw material costs (wool, silk \& cotton), script charges, and complexity charges, washing and dying expenses and overhead costs. The author also points to the marketing of the carpet industry terming it insignificant.

2) Venkatappa (1977) in his study titled "Problems and Prospects of Weavers' Co-operatives" found inefficiency in the organisational set up in the form of defective management and poor administration among the weavers' co-operatives in Karnataka.

Volume 6 Issue 12, December 2017 


\section{International Journal of Science and Research (IJSR) \\ ISSN (Online): 2319-7064}

Index Copernicus Value (2016): 79.57 | Impact Factor (2015): 6.391

3) R.B.Choubey (1978) conducted a study with the title "Problems and Prospects of Weavers Co-operatives in Bihar." Acute financial crisis was observed to be the main problem faced by Weavers' Co-operatives in Bihar. He proposed for the establishment of a separate wing in the Central Co-operative Bank for providing financial assistance to these societies

4) F.M Hassanain (1980) pointed in his book about various traditional crafts of Kashmir like Namdhas, Shawls, Woodcarving, Silk, Willow Work, Chain stitch, paper machine etc. he points towards the relevance and importance of handicraft sector especially for the Kashmir economy. The environment of the state being more appropriate for the small and cottage industries and handicrafts industry among the others is the oldest traditional cottage industry in the state. The author also throws some light on the suffering of this sector mainly due to its unorganized structure, with additional constraints of lack of skilled labour, lack of training centres each of technology, absence of market intelligence, poor infrastructure and institutional framework.

5) Basher Ahmad (1980-81) in his study, "problems of marketing the handicraft products of Kashmir" pointed out the state of efficiently dealt with by the government, there is a tremendous scope for the development of this sector of the state economy. Jammu and Kashmir has been far behind in industrial development as compared to other industrially developed states of the country. The study finds that the major problem of handicraft industry has been the disposal of products at remunerative prices.

6) R.C. Suneja (1982) in his book "Indian Rural Economics" has stated that handicrafts industry in India, besides helping to solve both social and economic problems of the village craftsmen and the vulnerable sections of the society, has to play an important role in earning valuable foreign exchange for the country.

7) R.V. Rao (1982) in his book "the Role of Cottage and Small Industries" analysed the handicaps of the handicraft industry as insufficiency of raw materials, lack of finance, inadequate marketing and old techniques of manufacture. For the revival of handicraft sector, he suggested to organise separate industrial co-operative societies for persons engaged in different crafts.

8) Dr. Vivek Renjan Bhattacharya (1982) in his book "New Strategy of Development in Village India" is of the opinion that Indian handicrafts are unanimously acknowledged as the very best and they are the true symbols of the spirit of the country. He also wrote that Indian artisans work for the finest, but they do not know anything about the world market and latest designs.

9) Vincent and Anu (1982) in their study revealed the problems and issues related to the exports of handicrafts sector. This paper provides an outline of how the production and distribution of handicrafts/ handlooms is organized leading to the expansion of exports in this sector. Following problems associated with handicraft sector have been briefly discussed.

- Scarcity of working capital.

- Inadequacy of raw material supplies.

- Shortage of skilled labour

- Inappropriate technology together with lack of design innovation.
- Delivery problems of the existing markets.

- Further this paper puts forward some preliminary suggestions as to how they may be resolved, to ensure that this sector lines up to the expectations.

10) C.R. Madan (1983) in his book "India's Developing Villages" stated that handicraft articles appeal to customers principally through their distinctive and artistic designs. He suggested that there should be a planned development to improve the handicraft industry by avoiding middlemen and by increasing the resources of production.

\section{Methodology}

Research methodology plays an important role in any investigation. Unless the methodology is correct, the analysis and conclusion may not be scientific. Our study is based upon descriptive research. The present research uses both primary as well as secondary data for analysis purpose

\section{Statistical tools}

\section{a) Average mean}

To carry out the average figure of any phenomenon simple or average mean is used, it can be find out by sum of items divided by total number of items

\section{b) Growth Rate}

To work out growth rate of handicraft sector in terms of production and exports

Following formula has been used:

Growth rate $=\frac{Q t-Q t-1}{Q t-1} \times 100$

Where,

$\mathrm{Qt}=$ quantity in current period

Qt-1=quantity in previous period

\section{c) Correlation}

To work out the relation between the following variables Karl Pearson's coefficient of correlation has been used;

Production - exports.

Following formula has been used to calculate coefficient of correlation;

$$
\mathrm{r}=\frac{\sum X Y}{\sqrt{\Sigma X^{2}} \sqrt{\Sigma Y^{2}}}
$$

$r=$ Karl Pearson's coefficient of correlation.

\section{d) Chi square}

A very powerful test for testing the significance of the discrepancy between theory and experiment was given by Prof.Karl Pearson in 1900 and is known as "chi square test of goodness of fit" . It enables us to test the validity of the deviation of hypothesis or expectational frequencies from observational or experimental frequencies at a fixed level of significance which is always taken in advance.

To test the null hypothesis, chi square test of goodness of fit has been used.

The following formula is used:

$$
x^{2}=\sum\left[\frac{\mathrm{fi}-\mathrm{ei}}{\mathrm{ei}}\right]^{2}
$$




\section{International Journal of Science and Research (IJSR) \\ ISSN (Online): 2319-7064 \\ Index Copernicus Value (2016): 79.57 | Impact Factor (2015): 6.391}

Where fi is a set of observed (experimental) frequencies and ei is the corresponding set of expected (theoretical or hypothetical) frequencies

\section{e) Level of significance}

The probability ' $\alpha$ ' that a random value of the statistic $t$ belongs to a critical region is known as the level of significance. The level of significance is always fixed in advance before collecting the sample information. The levels of significance which are usually used in testing of hypothesis are $5 \%$ and $1 \%$.

In this research work 5\% level of significance is applied

\section{Interpretation of Data and Fulfilment of Objectives}

\subsection{Contribution of handicrafts to state economy (GSDP)}

Table 1 contribution to GSDP

\begin{tabular}{|c|c|c|c|}
\hline Year & $\begin{array}{c}\text { Production } \\
\text { In terms of crore Rs. }\end{array}$ & $\begin{array}{c}\text { GDSP at } \\
\text { current prices }\end{array}$ & $\begin{array}{c}\text { Percentage Share } \\
\text { to state economy }\end{array}$ \\
\hline $1999-2000$ & 633.03 & 15659.81 & 4.04 \\
\hline $2000-01$ & 696.33 & 16699.53 & 4.17 \\
\hline $2001-02$ & 765.94 & 18039.53 & 4.25 \\
\hline $2002-03$ & 775.00 & 20325.91 & 3.81 \\
\hline $2003-04$ & 821.53 & 22194.43 & 3.70 \\
\hline $2004-05$ & 887.00 & 24265.04 & 3.66 \\
\hline $2005-06$ & 900.00 & 26537.22 & 3.39 \\
\hline $2006-07$ & 950.00 & 29029.74 & 3.27 \\
\hline $2007-08$ & 1614.59 & 31793.04 & 5.08 \\
\hline $2008-09$ & 1100.00 & 21235.52 & 5.18 \\
\hline $2009-10$ & 1050.00 & 2100.92 & 5.45 \\
\hline
\end{tabular}

Source: Economic survey $J \& K, 2010-11$

\subsection{Annual growth rate of production}

Table 2: Growth rate

\begin{tabular}{|c|c|c|}
\hline Year & $\begin{array}{c}\text { Production in } \\
\text { Rs.lakhs }\end{array}$ & $\begin{array}{c}\text { Annual } \\
\text { growth rate }\end{array}$ \\
\hline $2003-2004$ & 821.53 & - \\
\hline $2004-2005$ & 887.00 & 7.96 \\
\hline $2005-2006$ & 900.00 & 1.46 \\
\hline $2006-2007$ & 950.00 & 5.55 \\
\hline $2007-2008$ & 1614.59 & 69.95 \\
\hline $2008-2009$ & 1100.00 & -31.87 \\
\hline $2009-2010$ & 1000.00 & -9.09 \\
\hline $2010-2011$ & 1650.00 & 39.39 \\
\hline $2011-2012$ & 1815.33 & 10.02 \\
\hline $2012-2013$ & 1843.00 & 1.52 \\
\hline
\end{tabular}

Source: calculated from the data obtained from economic survey $J \& k$, 2013-2014

In above table, the annual growth rate of production has been shown. In 2004-05 the total production has been increased to 887.00(in terms of crore Rs.) at an annual growth rate of $7.96 \%$. During 2005-06 it increase at a rate of $1.46 \%$.the highest annual growth rate was found in 2007-08, points out a growth rate of $69.5 \%$. However the production has been declined to 1100 in the session of 2008-09 and shows a declined trend in the growth rate, during this period the annual growth rate falls to $-31.87 \%$. In $2009-10$ it continues to fall but a smaller reduction than a previous figure, during this period it was $-9.39 \%$. . The annual growth rate of production once again starts to attain a rising pace and it reached to $39.39 \%$ in $2010-11$. During 2012-13, the production grow at an annual rate of $1.52 \%$.

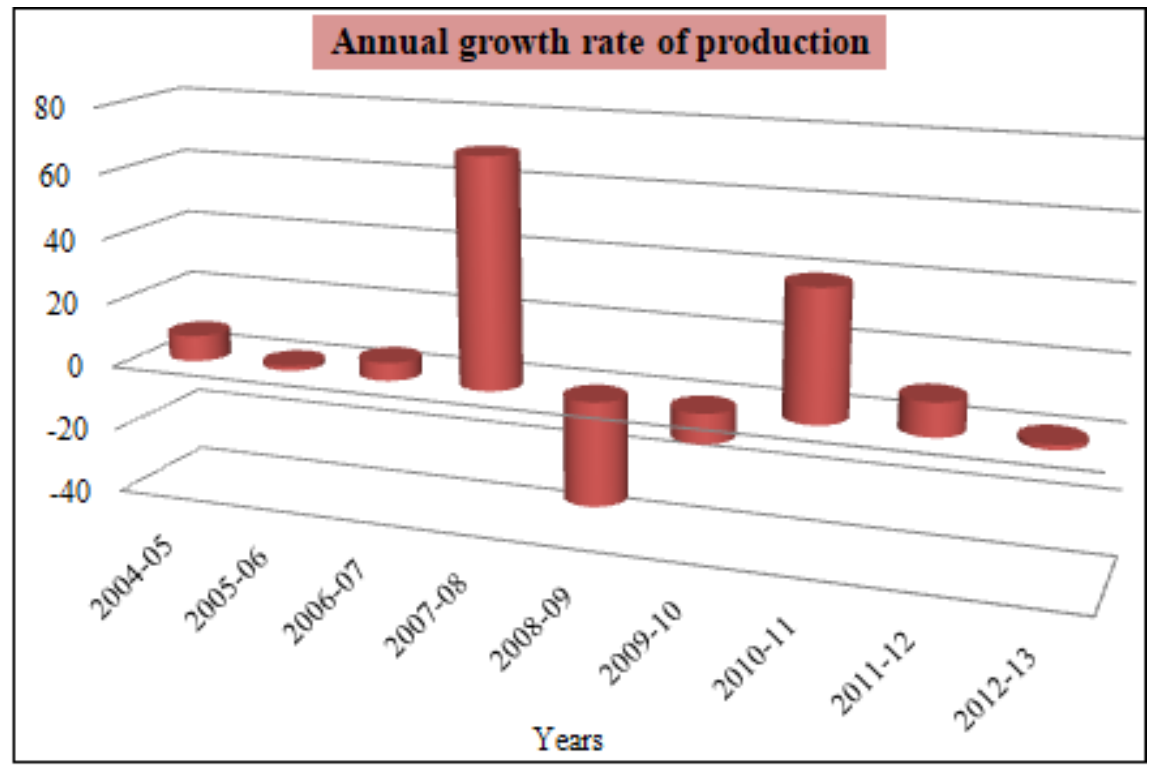

Figure 1: Represents annual growth rate of production

Table 3: Annual growth rate of exports

\begin{tabular}{|c|c|c|}
\hline Year & Exports in Rs.lakhs & Annual growth rate \\
\hline $2003-2004$ & 595.00 & - \\
\hline $2004-2005$ & 642.00 & 7.89 \\
\hline $2005-2006$ & 705.00 & 8.93 \\
\hline $2006-2007$ & 758.00 & 7.51 \\
\hline $2007-2008$ & 1200.47 & 58.37 \\
\hline $2008-2009$ & 705.50 & -41.27 \\
\hline
\end{tabular}

\begin{tabular}{|c|c|c|}
\hline $2009-2010$ & 661.27 & -6.26 \\
\hline $2010-2011$ & 1004.10 & 51.84 \\
\hline $2011-2012$ & 1643.37 & 63.66 \\
\hline $2012-2013$ & 1538.28 & -6.39 \\
\hline
\end{tabular}

Source: calculated from the data obtained from economic survey J\&k,2013-2014

\section{Volume 6 Issue 12, December 2017}




\section{International Journal of Science and Research (IJSR) \\ ISSN (Online): 2319-7064}

Index Copernicus Value (2016): 79.57 | Impact Factor (2015): 6.391

In the above table, the annual growth rate of exports has been revealed. In 2004-05 the total value of exported handicrafts items has been increased to 642.00 (in terms of crore Rs.).The annual growth rate of exports has increased at the rate of $7.89 \%$ during this period. During 2005-06 it increase at a rate of $8.93 \%$. The highest annual growth rate was found in 2011-12, points out a growth rate of $63.66 \%$. However the exports were declined in the session of 200809 and shows a declined trend in the growth rate, during this period the annual growth rate falls to $-41.27 \%$. In 2009-10 it continues to fall and during this period it was $-6.26 \%$. . The annual growth rate of exports once again attain a rising trend and it reached to $51.84 \%$ in 2010-11. During 2012-13, the exports declined at a rate of $-6.39 \%$.

\subsection{Hypothesis testing}

Table 4: Chi square test

\begin{tabular}{|l|l|l|l|l|}
\hline$F i$ & $E i$ & $f i-e i$ & $(f i-e i)^{2}$ & $(f i-e i)^{2} / e i$ \\
\hline 4.04 & 4.18 & -0.14 & 0.0196 & 0.0046 \\
\hline 4.17 & 4.18 & -0.01 & 0,0001 & 0.000023 \\
\hline 4.25 & 4.18 & 0.07 & 0.0049 & 0.00117 \\
\hline 3.81 & 4.18 & -0.37 & 0.1369 & 0.0327 \\
\hline 3.70 & 4.18 & -0.48 & 0.2304 & 0,05511 \\
\hline 3.66 & 4.18 & -0.52 & 0.2704 & 0.0646 \\
\hline 3.39 & 4.18 & -0.79 & 0.6241 & 0.1493 \\
\hline 3.27 & 4.18 & -0.91 & 0.8281 & 0.1981 \\
\hline 5.08 & 4.18 & 0.1 & 0.81 & 0.1937 \\
\hline 5.18 & 4.18 & 1 & 1 & 0.2392 \\
\hline 5.45 & 4.18 & 1.27 & 1.62 & 0.3875 \\
\hline$\sum=45.98$ & 45.98 & & & 1.326 \\
\hline
\end{tabular}

Source: Calculated from the data obtained from Economic survey of J\&K 2010-11

To know the validity of null hypothesis, it is necessary to test the hypothesis by applying appropriate statistic. The validity has been tested by applying the chi square test of goodness of fit

Table 5: Computation Values

\begin{tabular}{|c|c|c|c|c|}
\hline$\sum \mathrm{fi}=45.98$ & $\begin{array}{c}\text { Level of } \\
\text { significance } \\
=5 \%\end{array}$ & $\begin{array}{c}\text { Degrees of } \\
\text { freedom }=\mathrm{n}- \\
1=11-1=10\end{array}$ & $\begin{array}{c}\text { Tabulated } \\
\text { value }=18.31\end{array}$ & $\begin{array}{c}\text { Computed } \\
\text { value }=1.326\end{array}$ \\
\cline { 1 - 3 } $\mathrm{e}_{\mathrm{i}}=45.98$ & & \\
\hline
\end{tabular}

Source: values taken from table 4 and chi square table

Since computed value of chi-square (1.326) is much smaller than the tabulated value (18.31) at 5\% level of significance for 10 degrees of freedom. Our null hypothesis is highly significant and we may accept null hypothesis and conclude that contribution of handicrafts to the GSDP has increased over period of time

\section{Schemes Launched}

With the aim of revitalizing such crafts and to tap the full potential of both the Handlooms and Handicrafts sectors, certain fresh interventions have been proposed and the Central and the State Governments have implemented some generic schemes in these sectors for holistic growth and development of handicrafts and handloom sector in the state. Also, recognizing the special needs and problems of artisans several development measures were initiated. Government of India laid stress on the various development measures to be undertaken by the Central and the State Governments to improve the living standard of the artisans and make an effort to bring them on par with the other developed societies in the country

\section{Dastkar Finance}

Salient Features: This scheme provides financial assistance to the artisans, members of cooperative societies and craftsmen engaged in Handicraft activities like shawl and carpet making, crewel and chain-stitch embroidery, gubba making, paper-machie, kanni shawl, tapestry, namda embroidery, zari embroidery, copperware making, wood carving, willow-wicker work, fur and leather work and shawl embroidery.

Objectives: The credit plan aims at providing credit to the artisans engaged in different handicraft activities for setting up self employment generating units so as to enable them to start their independent ventures. The scheme envisages $90 \%$ financial assistance in the form of loan from the banks and $10 \%$ promoter's contribution. In addition to this, there is an element of interest subsidy to the extent of $5 \%$ on the loan component to be provided by the state government.

Eligibility: Under this scheme, artisans and crafts-men can obtain a loan ranging from Rs. 0.15 lakh to Rs. 3.00 lakh depending upon the nature of activity. As far as the quantum of finance is concerned, the artisans associated with namda production are eligible to get a loan facility of Rs. 20,000 while as wood-carvers, fur/leather goods manufacturers can obtain loan to the tune of Rs. 50,000. Paper-machie and willow wickers are eligible to avail a loan facility of Rs. 30,000 and Rs. 10,000 respectively.

The repayment mechanism includes moratorium of one or two months and the borrower has to repay the loan amount within a period of two and a half years depending upon the nature of the activity. Up-to a loan amount of Rs. 25,000 the borrower has to furnish security in the shape of hypothetication of articles/stock and a third party guarantee of one person. Above Rs. 25,000 the borrower has to give a security in the shape of two persons besides hypothetication of articles/stock.

\section{Artisan Credit Card (ACC) Scheme:}

Salient Features: The Artisan Credit Card scheme has been devised by Indian Banks Association (IBA) to provide hassle free credit facility to artisans. The scheme approved by RBI and the Development Commissioner (Handicrafts) has been adopted by the banks for implementation.

Objectives: The ACC scheme has been formulated to provide adequate and timely assistance to the artisans from the banking institutions to meet their credit requirements of both investment needs as well as working capital needs in a flexible and cost effective manner. The scheme has been implemented both for rural as well as urban areas.

Eligibility: All artisans involved in production / manufacturing process (and otherwise eligible for credit facilities for carrying out the proposed activities under any of the existing bank schemes) would be eligible. Preference

\section{Volume 6 Issue 12, December 2017}




\section{International Journal of Science and Research (IJSR) \\ ISSN (Online): 2319-7064}

Index Copernicus Value (2016): 79.57 | Impact Factor (2015): 6.391

would be given to artisans registered with the Development Commissioner (Handicrafts).

The credit limit is fixed based on the assessment of working capital requirements as well as cost of tools and equipments required for carrying out manufacture process. The maximum limit sanctioned under this scheme is Rs. 2 lakh. The limit is to be utilized as revolving cash credit and will provide for any number of drawls and repayments within the limit. Up to a sum of Rs. 25,000, the margin money is zero. For a sum of Rs. 25,000 and up to Rs. 1 lakh, margin money is 20 percent of the amount and for a sum of Rs. 1 lakh and up to Rs. 2 lakh, margin money is 25 percent of the credit.

\section{Export Promotion Scheme}

Salient Features: This scheme is intended to promote export of Handicrafts. The key features of this particular scheme include:

1) Product Development

- Workshop and training programme in export procedures/ management and in packaging;

- Training of artisans/Master-craft people/designers;

- Workshop/seminars in India and abroad; and

- Selection of artisan for development of proto types for exports and invitation to foreign designers.

2) Publicity and marketing

3) Social and other welfare measures

Objectives: The objective of the scheme is to promote export of handicrafts, including hand knotted carpets from India. Initiatives such as identification of handicrafts concentration area for undertaking research and studies in order to identify markets abroad, taste and fashion, prevailing designs, development of exportable products and identify prevailing designs.

Eligibility: The eligibility under this scheme is extended to central/state Handicraft corporation, council of handicraft development corporation (COHANDS), Apex cooperative societies, NGO's registered under Society's Act, and other such organizations engaged in the development and promotion of Handicraft sector registered under any other Statutory Acts, India Exposition Mart, Registered Handicrafts, exporters, reputed designers/technologists approved office of the DC. During 2005-06, Rs. 1259.90 lakh has been allocated under Export Promotion Scheme, of which an amount of Rs. 1180.78 lakh has been spent up to February 2006.

\section{Human Resources Development Scheme (HRD)}

Salient Features: The Scheme has five key components.

1) Training through established institutions,

2) Training in innovative designs for artisans involved in hand block printing, terracotta, etc.,

3) Training of artisans/ SHG leaders/ NGOs in nontechnical skills such as micro finance/ entrepreneurship development/ preparation of business plans/ preparation of project reports/ packaging/export procedures/ documentation,

4) Conducting seminars/ workshops for dissemination and creation of awareness about schemes/ programmes, technological developments, market intelligence, amongst artisans and stakeholders, and
5) Training through Guru Shishya Parampara for passing the expertise along with appropriate technology and indigenous methods by master crafts persons to the artisans and provide gainful employment in rural areas.

Objectives: The aim of the HRD Scheme is to provide trained and qualified workforce capable of establishing a strong production base, coupled with improvements in quality and use of appropriate techniques, processes and innovative designs to meet present day market requirements.

Eligibility: Under this Scheme financial assistance is extended to the central/state handicraft corporation, cooperative societies, Handicraft Societies and other institutes dealing in handicrafts.

The Mid-Term Appraisal of 11th Plan has indicated that nearly $88 \%$ of the beneficiaries reported increase in production after training and accessibility to new designs and techniques, and about $80 \%$ of the beneficiaries felt that the impact of these trainings/workshops is long term.

\section{Research and Development Scheme (R\&D)}

Salient Features: The R\&D Scheme was introduced in 1956-57 as a Central Sector Scheme on all India basis. The Scheme consists of five components.

1) Conducting surveys/ studies of specific crafts for which adequate information is not available, including problems related to availability of raw material, technology, design, and common facilities; living and working conditions of artisans and issues related to brand building and promotion of Indian Handicrafts,

2) Census of Handicraft Artisans,

3) Registration of Crafts under Geographical Indication Act,

4) Setting up/strengthening Testing Laboratories, and

5) Assistance to exporters for adoption of global standards and bar coding, including Handicrafts Mark for generic products.

Objectives: The main objective of this scheme is to have a regular system of feedback of economic, social, aesthetic and promotional aspects of various crafts and artisans in the sector and to address the issue arising out of WTO stipulations.

Eligibility: Assistance under the scheme is extended to an organization registered under any of the Statutory Acts (Companies Act 1956 and Societies Registration Act 1860) or registered with any bodies like Development Commissioner (Handicrafts) etc., or universities and recognized research institutions. Generally such assistance is not extended to any individual unless he is an eminent scholar or a person associated with the promotion of handicrafts for a long time. During 2005-06, Rs. 329.90 lakh has been allocated for undertaking various Research and Development schemes and 2 studies were also sanctioned during the same period.

\section{Conclusion and Main Findings}

\subsection{Conclusion}

Handicraft industry occupies an important position in the economic structure of Jammu And Kashmir State. From 


\section{International Journal of Science and Research (IJSR) \\ ISSN (Online): 2319-7064}

Index Copernicus Value (2016): 79.57 | Impact Factor (2015): 6.391

times immemorial, handicraft sector has remained a key economic activity in the state. The reason being that handicraft activities are best suited to the state as they are more labour intensive and less capital intensive as well as being environment friendly. Besides, it is one such sector that has great employment potential. Handicraft products of the state are known for their high quality craftsmen ship, attractive designs and functional utility. Kashmiri art and crafts have no parallel in design and quality; therefore, they continue to occupy a unique position in the national as well as the inter-national market. The handicrafts industry of $\mathrm{J} \& \mathrm{~K}$ is an important sector contributing to overall development of current and other allied sectors in terms of wealth and employment creation thus occupying an important place in the economy of $\mathrm{J} \& \mathrm{~K}$. The finding from the literature review represents unique position of $\mathrm{J} \& \mathrm{~K}$ handicrafts in improving social and economic conditions of Jammu \& Kashmir. From societal point of view it is mostly preferred sector after agriculture because of suitable conditions in terms of topography of state. It provides opportunities to its citizens to enhance their standard of living and helps them to meet their social and psychological requirements of a sustainable life. In economic terms it helps in generation of aggregate employment and raising per capita income of state and hence contributes to State Gross Domestic Product (SGDP) in particular and National Income in general. Jammu \& Kashmir handicraft industry facilitates technical know-how between state skilled manpower and international market players through foreign exchange. Though the strength and opportunities exists in J\&K handicrafts industry, but need exists to develop and implement strategies in order to explore and develop the hidden agenda thereby adding the value to socio-economic contribution of $\mathrm{J} \& \mathrm{~K}$ handicraft industry to the state.

To conclude it can be said that the Handicraft industry of Kashmir has assumed a great and undoubted importance so far as the needs of the state economy is concerned. This vital sector has grown considerably in generating employment and volume of production. It has also contributed towards earning foreign exchange for meeting the needs of the country as well as the state

\subsection{Main findings}

The main findings of the study are:

- Huge Market potential

- Flexible Production \& design

- Cheap labour

- Suitable to Climatic conditions

- Huge employment opportunities

- Foreign revenue generation

- Eco-friendly.

- Needs less investment.

- Export oriented.

- A sense of self-dependence among masses.

\section{Opportunities}

- Huge demand in both domestic as well as foreign markets

- Develops Tourism industry of J\&K .

- Design sensibility.
- Handicraft products are also preferred by Real Estate players to add value in their businesses.

- E-commerce to channelize handicraft products of J\&K

\section{Weakness}

- Underdeveloped infrastructure

- Lacks global exposure

- Lack of customer feedback system.

- Less interest among youths.

- Confined mostly to rural areas.

- Still old techniques prevail.

- Unorganized sector.

\section{References}

[1] Nabi, Gh. (1975): "Economic Appraisal of Carpet Industry in J\&K State”, M.Phil Dissertation in the University of Kashmir, pp. 6-186.

[2] Venkatappa, Problems and Prospects of Weavers' Cooperatives, Indian Co-operative Review, Bombay, Vol.IX V, No.3, 1977.

[3] R.B. Choubey, Problems and Prospects of Weavers Co-operatives in Bihar, Indian Co-operative

[4] Hassanain, F.M. (1980), "Heritage of Kashmir, Gulshan Publishers-Srinagar, pp. 165-180.

[5] Ahmad, B. (1980-81), "Problems of Marketing the Handicraft Products of Kashmir", M.Phil dissertation in the University of Kashmir, P. 23-132.

[6] R.C. Suneja, Indian Rural Economics, Bankers Publishing Company, Bombay, 1982, p.no.190.

[7] Rao, R.V."Cottage and Small Industries and Planned Economy”, Delhi Sterling Pub. Pvt. Ltd. 1982.

[8] Vivek Renjan Bhattacharya,(Dr), New Strategy of Development in Village Industry, Metropolitan Book Co. Pvt. Ltd, Bombay, 1982, p.no.139.

[9] Vincent C and Anu Weston (1982) "The role of handicraft exports problems and prospects", Overseas Development Institute, Vol XX, No. 10.

[10] C.R. Madan, India's Developing Villages, Print House (India), Lucknow, 1983, p.no.289. 